\title{
Language, Identity, and Nation: The Special Case of Belarusian State- and Nation-Formation ${ }^{1}$
}

\author{
BY \\ ALENA MARKOVÁ
}

Throughout its history, Belarus has experienced several periods of its own statehood as well as several attempts at re-establishing it, such as the interwar Belarusian People's Republic (BNR), and others. Lately, the short-lived attempt at independence of the BNR has become the subject of increased attention of Belarusian researchers and publicists on the occasion of its 100th anniversary (Chernjakevich, 2018; Kavalienia and others, 2018; Šupa 2018).

However, of all past periods and attempts, there is one truly unique and especially ambiguous case of Belarusian nation- and state-formation. This particular case took place after the dissolution of the BNR (1919) and followed several other failed attempts at statehood. ${ }^{2}$ This unique case influenced both directly and profoundly recent Belarusian history as well as contemporary Belarusian society, but most importantly it affected Belarusian nation and identity formation. Therefore, our attention will be primarily focused on the nationality policy of Belarusisation and on analysing the processes and mechanisms of nation-building and identity formation in the framework of Belarusisation as it took place in the Belarusian Soviet Socialist Republic (BSSR), which, in its final form, emerged in 1922. In addition, the analysis will examine the post-Soviet period of independent Belarus as well as the new wave of national movement, the so called Neo-Belarusisation, which took place from 1990 to 1995.

\footnotetext{
1 The publication was supported by the Czech Science Foundation (GA ČR) - GAČR 18-18108S, Neo-Belarusization Processes in Post-soviet Belarus in the National Independence Era (1990-1995) Charles University, Faculty of Humanities, 2018.

2 For example, the Belarusian Soviet Socialist Republic (BSSR), which was for the first time declared on January $1^{\text {st }} 1919$ and the succeeding Lithuanian-Belarusian Soviet Socialist Republic (Lit-Bel) (1919).
} 


\section{Belarusisation}

What then was Belarusisation? Belarusisation was a soviet nationality policy initiated by the Bolsheviks. It took place in the Belarusian Soviet Socialist Republic (BSSR). In Belarus, the nationality policy was officially introduced and implemented in 1924 and it lasted until 1929, for almost 5 years. The Belarusisation policy could be viewed as the massive Soviet support of the processes of Belarusian nation-building and nation-formation in the interwar period.

First of all, Belarusisation meant the significant and intensive promotion of the national language (i.e. Belarusian language, which was the mother tongue of the majority of the population of the Belarusian Soviet Socialistic Republic of that period). This promotion was accompanied by goal-directed language planning. The national language was promoted in all spheres of state and party administration, as well as in the education system; it was introduced into the academic field, and boosted in public discourse (i.e. Belarusian was the language of the press and so on). At the same time, the development of national culture as well as of Belarusian academic studies gained substantial and massive state support.

Yet another essential part of Belarusisation was the so-called "indigenisation" (korenizatsia), which meant the promotion of ethnic Belarusians into leading working and administrative positions in the state administration, into the ranks of the dominant Communist party, within the public service, educational system, and into the cultural and academic spheres.

This policy was originally drafted, developed and discussed already in 1921 during the 10th Congress of the Russian Communist Party (Bolsheviks) (RKP(b)), and then again two years later in 1923 during the 12th Congress of the RKP(b). In Soviet Belarus the nationality policy was started only one year later, in 1924 (Pastanovy i rezaliucyji UsieKP(b) i KP(b)B pa nacyjanaĺnym pytanni 1926, 39-44).

What reasons did the Bolsheviks have for launching the nationality policy in 1924? There are several plausible answers which one could consider. One reason could be the echo of the foregone threat of an alternative statehood in the Belarusian People's Republic. The Belarusian People's Republic wasn't successful because it couldn't receive recognition on the international political stage and thus it disintegrated in 1919. Nevertheless, it was a serious attempt at re-gaining and defending a Belarusian statehood, which wasn't derivative or related to the Bolshevik state or Bolshevik ideology.

However, probably the main reason behind the initiation of Belarusisation was the urgent necessity to promote, consolidate and first of all localise Soviet power and Soviet (i.e. communist) ideology in ethnically non-Russian areas and 
republics of the Soviet Union such as Ukraine, Belarus and others. It was assumed that in order to succeed in this power transition, the regime needed to use the local language and thereby bring the Soviet government closer to the local ethnically non-Russian population (Stalin 1934, 112).

Thus, we could argue that the policy was in essence based on very pragmatic and almost mercenary initial reasons, and that these were the reasons which stood behind a nationality policy in a state which proclaimed the primacy of the ideology of proletarian internationalism. To avoid confusion: from the Bolshevik point of view, this policy was not intended as a means to promoting and establishing a truly independent Belarus, nor was it supposed to contribute to the awakening of national identity. Yet the processes initiated by the policy nonetheless lead to a phenomenon similar to a national awakening typical to the efforts of classical national movements of the 19 th century.

\section{Preconditions of Belarusisation}

The intensive processes of Belarusisation in the course of the 1920s corresponded to, or supplemented, the processes of modern Belarusian national formation, as a nation emerging from an ethnical group. Or, to use the terminology of Anthony Smith (Smith 1991), one might argue that in the course of Belarusisation, i.e. in the course of this intensive nation-formation, a leap from an ethnic category to an ethnic community (ethnie) was realised.

Belarusisation emerged, very much like a typical European national movement, at the moment when the Belarusian language had become almost completely driven out of the public space, social communication, out of administrative offices, out of the press, education and schools. This was the result of alternating waves of Polonisation and Russification. The second important aspect of the situation was that the majority of the ethnically Belarusian population (which in the early 20 th century was predominantly rural) often understood its identity mainly as belonging to a local ethnical group (this is the phenomenon of so called "local people”, or tutejšyja, tutejšaść).

In other words, they did not perceive their identity as belonging to an abstract nation. Their identity was first and foremost a local one where the local (Belarusian) language served as a marker of belonging to a certain social group or to a local ethnic group. In this sense, language was not understood as an abstract attribute of an abstract nation. This particular aspect was yet to play a significant and unfavourable role during the course of Belarusisation and during the accompanied massive promotion of the Belarusian language, which happened "from above". Due to the local population's view of the Belarusian language, the often unprestigious 
local language was not immediately well-received and did not easily become a part of the new everyday life reality of the new socialist state, the BSSR.

\section{Language and its Promotion}

As a part of the new nationality policy, Belarusisation, attempts were made at a definitive codification of the Belarusian language. The codification as such was significantly complicated by the considerable linguistic fragmentariness of local dialects.

Along with the process of codification, a process of intellectualisation of the national language also took place. Intellectualisation included the process in which the newly codified national language develops and takes its final shape (Hroch 2000, 77). Within the framework of intensive support for publications in Belarusian (that is academic as well as popular or mass-produced), Belarusian literature and poetry were being supported and developed, as well as journalism, Belarusian theatre, academic monographs, translations into Belarusian, and so on (Głogowska 1996).

For example, newspapers started being published in Belarusian. Starting on January 1st 1927, the central periodical of the Belarusian communist party Zviazda was to be published in Belarusian too. Regional periodicals also began to be published in Belarusian (Pastanovy i rezaliucyji UsieKP(b) i KP(b)B pa nacyjanaĺnym pytanni 1926, 69-71). Direct support was provided for Belarusian theatre: there were no less than three national theatres in Belarus during the Belarusisation period - the Belarusian State Theatre-1 (Bielaruski dziaržaŭny teatr) or BDT-1 (1920, Minsk), the BDT-2 (1926, Vitebsk), and probably the most popular, the Travelling State Theatre (Bielaruski dziaržaŭny vandroŭny teatr) founded by Uladzislaŭ Halubok. This third national theatre performed mostly in regions outside the capital (later in 1931 it became BDT-3). There were other professional and amateur theatre ensembles as well, which frequently staged plays in Belarusian.

The production of artistic literature, such as fiction and poetry, in Belarusian was also generously supported. Many authors considered today the classics of Belarusian literature, worked or started their authorship during this period (Źmitrok Biadulia and Jakub Kolas are just two examples of writers whose works have become parts of the Belarusian cultural heritage).

Belarusisation was accompanied by a phenomenon typical of the beginnings of a national movement, the so-called classical praise or celebration and defence of the national language, which is still in need of symbolic justification and of the defence of its usefulness (Hroch 2015, 205). Such argumentation was often sought in the 
glorious national past, such as, for example, in the history of the Grand Duchy of Lithuania, i.e. the Golden Age of Belarusian history. In that period, Belarusian was the language of state administration as well as the language of all the Statutes, of this prime and prominent example of law-making.

The above-mentioned celebration, defence, and glorification of the Belarusian language, was to be found not only in the popular production of Belarusian literary classics, but also and primarily on the academic level (Ihnatoŭski 1926, 100; Pičeta 2005, 53-154; Harecki, Dziaržynski and Karavai 1926, 251; Harecki 1921, 38), that is in the form of educational literature, school textbooks, and academic studies such as the works of the historian Uladzimir Pičeta, the first rector of the Belarusian State University, founded in 1921. In his 1924 work, Belarusian Language as a National-Cultural Factor, Pičeta presented scientific grounds for the uniqueness of Belarusian as a full-fledged language of independent value (Picheta 1924).

At the same time the standardisation of Belarusian also took place. This activity was mainly associated with the Institute of Belarusian Culture (Inbielkult) and its departments and committees (most importantly the Department of Belarusian Language and Literature, but also others), which was founded in 1922. One of the many achievements of the Institute was the elaboration and publication of textbooks and dictionaries with Belarusian academic terminology and technical terms in the fields of military, technical, and medical science (Cvikievič 1926; Kaściuk and Petrykaŭ 1993).

However, first and foremost one of the most important aspects of Belarusisation was the promotion of Belarussian in all areas of state administration, party apparatus, and public discourse. But even more significant was the compulsory introduction of Belarusian into schools at all levels - from elementary school to universities. An exam in Belarusian language became an obligatory prerequisite for admission to universities (Praktyčnaje vyrašennie nacyjanaĺnaha pytannia ŭ Bielaruskaj Savieckaj Sacyjalistyčnaj respublicy 1928, 141).

Finally, the full equality of the Belarusian language was secured legislatively.

Since 1920, the principle of equality of Belarusian with three other state languages (Polish, Russian, and Yiddish) had been in force. ${ }^{3}$ Such a situation was truly unique and unprecedented: interwar Belarus was a state with four official languages - Belarusian, Polish, Russian, and Yiddish. Later, in the Constitution of the BSSR from 1927, this linguistic equality was confirmed alongside the right of minorities to use their national languages. BSSR was the only Soviet Republic to guarantee the equality of all state languages in the Constitution.

The equality of Belarusian, Yiddish, Polish, and Russian was protected by the Declaration of Independence of the Belorusian Soviet Socialist Republic of 31 July 1920. 


\section{Identity Formation}

Particularly close attention should be paid to the processes of identity formation and to the actual model of national identity which emerged and was being promoted during the Belarusisation period, 1924-1929. The newly formulated national identity effectively distanced itself from the Soviet nationality policies, represented in the all-pervasive motto that they should be "national in form but socialist in content" (Stalin 1952, 133). The new conception was primarily based on the cultural, ethnic, linguistic and historical uniqueness of Belarus's independent state formation.

Firstly, a new conception of Belarusian national history was developed, which in itself is an important feature. This conception deserves particular attention. In the new Belarusian history (especially in the works of Uladzimir Pičeta and then also Usievalad Ihnatoŭski) the European-ness of Belarusian history was emphasised as well as the long-term independence from neighbouring countries - mainly from Russia and Poland - and its independent national development (Ihnatoŭski 1926; Pičeta 2005).

One of the crucial historical periods stressed in the new conception was the Principality of Polatsk, which was perceived as the first Belarusian state. Secondly, it was the Smolensk Principality, which had a significant role due to the fact that it was comprised of essential parts of the ethnic Belarusian territory, which influenced the independent historical development of the Belarusian lands (Pičeta 2005, 98101). Very much like in the conception of national history of the Czech national revivalist František Palacký, which was based on the mutual "coexistence and confrontation" of Czechs with their German neighbours in the course of history (Kutnar and Marek 1997, 219-229), Belarusian national development, as well as its cultural and linguistic uniqueness, continuously contended with, distanced itself from, and also engaged in confrontation with, the neighbouring Russian and Polish states. Interestingly, this comparing and confronting pertained mainly to Russia and Poland and to their historical and cultural influence. There was, on the other hand, no symbolic distancing from or confrontation with the Lithuanians or the Ukrainians, as the new Belarusian history apparently did not need to distance itself from them. This was due to the fact that, in the course of history, Russia and Poland were the nations associated with language oppression, assimilation, and cultural domination. Consequently, the newly formulated conception of national history needed to disassociate itself from these two neighbouring states (Markava 2016, 189-190).

Another interesting aspect of the newly formulated national identity was the emphasis on the common ethnical origin of Belarusians, on their separateness or on the independence of their ethnic development from the formation and development of other close ethnic Slavic groups or nations - especially from the Russians. Strong 
emphasis was placed on the ethnical purity of Belarusians which was the result of their isolation from invading forces and non-Slavic ethnical groups. Belarusians never experienced a major invasion of non-Slavic nomadic groups, and according to contemporaneous scholars they could be considered the "purest kind of a Slavic tribe" as such, which is how Ihnatoŭski (Ihnatoŭski 1926, 10) or Smolič in his studies and in his textbook on the Geography of Belarus phrased it (Smolič 1993, 126).

The common origin, common national history, cultural heritage, and glorious past were meant to empower and strengthen the rising national consciousness. All of the above-mentioned history, origin, and historical consciousness, were designed to build a common platform for the future unity of the Belarusian nation.

\section{Korenizatsia}

Another important aspect of the nationality policy was that within its framework the incomplete social structure of the ethnical Belarusian population was to be completed. These processes took place as part of the so-called korenizatsia, that is in the promotion of Belarusians into leading positions in state or party administration, in the educational system, and in academia. Korenizatsia involved the students of universities as well, with the actual effect of positive discrimination of applicants of peasant origin, which in that period in Belarus almost always meant ethnical Belarusians (Sobranie Uzakonenij i Rasporiazhenij Raboche-krestjanskogo pravitel'stva BSSR 1925, 1-2). Gradually, leading cultural and political elites of Belarusian origin emerged and the social structure of the population of the republic significantly changed.

Korenizatsia was initiated when the majority of the adult Belarusian population was illiterate and the Belarusian intelligentsia was very small. In the Russian Empire, the Belarusian population was not able to obtain middle or university education in their mother language, and social ascent often depended on assimilation and acceptance of the cultural and linguistic identity of the ruling ethnical group (Russian or Polish).

Thus, korenizatsia could be compared to the social emancipation of the Belarusian ethnic group which in this sense hadn't been very successful within the Russian Empire, where Belarusians as one of many disadvantaged non-ruling ethnical groups had only had very limited possibilities of social success.

\section{Belarusisation as a National Agitation}

The abovementioned processes of social, cultural and linguistic emancipation belong to the nationality policy of Belarusisation. These processes closely 
correspond to the linguistic, cultural and social programme of a national movement or to the demands of the social, cultural and linguistic emancipation of a national movement as defined by Miroslav Hroch (Hroch 2000). According to Hroch, a national movement passes through three phases in the course of its development: phase A, or the so-called academic phase, or the phase of scholarly interest, which is promoted by scholars and intellectuals whose activities target the non-ruling or non-dominant ethnical group such as Czechs, Slovaks or Belarusians within a multicultural empire. Phase A is usually followed by phase B, the phase of active national agitation. During this phase, national patriots (often called revivalists) make active efforts "to persuade members of non-ruling ethnical groups that they are actually members of a nation with a value of its own and the right to the same attributes of other nations already in existence." (Hroch 2000, 13). Then phase $\mathrm{C}$ follows. This is the phase of mass response and mass support of the national movement, political mobilisation, and finally a mass national movement. This phase involves the promotion of political demands. The arrival of this phase usually signals the success of the national movement.

The development of the phases, as well as the development of national demands, is mostly continuous and subsequent, i.e. from the demands of cultural and language emancipation to the demands of political emancipation, from phase A to C. At the symbolical end of a successful national movement stands a national state.

Therefore, the nationality policy of Belarusisation in Belarus of the interwar period and all related processes can be considered as a massive and active national agitation (or phase B) conducted by national revivalists. Ironically enough, some of these revivalists, whom we usually picture in the context of the 19th century, were in fact enthusiastic communists and fervent members of the Communist Party such as, for example, Usievalad Ihnatoŭski and others. Many were on the other hand without any political membership, such as the abovementioned author of one of the most well-known school textbooks of the interwar period, Arkadź Smolič.

\section{Uniqueness of the Belarusian Type of Nation-Building and Nation-Formation}

Thus, there are some obvious features that distinguish the Belarusian type of nation-building and nation-formation and make it unique. Firstly, the national agitation which was conducted in the situation of an incomplete nation-formation received massive support, and the national language and national cultural activities were promoted by state-sanctioned programmes.

Another unique feature was the fact that the demands for cultural development, of linguistic and cultural emancipation, were developed suddenly, very intensively 
and during a very short time period (the Belarusisation processes were limited to only five years and then their intensity rapidly declined), almost like in a pressure cooker.

Thirdly, and this is probably the main distinctive feature which makes these processes so unique - these processes took place in the situation of an already existing statehood. In most European national movements statehood comes afterwards, that is at the end of a national movement, when the social, language and political demands are fulfilled and a national state logically completes the trajectory of the successful national movement. The Belarusian national movement was not such a case. The Belarusian State (BSSR) had been established before the process of Belarusian nation-building could have been completed and before the demands of the national movement could be fulfilled. The statehood of the BSSR was symbolic in nature, because the state was a satellite of Moscow and depended on the central administration for its decision-making, whereas formally it was an independent state and even had the right of secession at its disposal, that is, it could theoretically leave the Soviet Union, which eventually did happen in the 1990s.

Active national agitation as well as acceptance of the national language by the general population were not, however, successful. The reason behind the failure can be seen in the high Russification of the majority of the urban population, in the cautious reaction of other social groups, peasants including, to the new state language, in the extremely short duration of the language agitation, and in other factors.

Another unique feature is that even though national agitation was not entirely successful, the failure did not endanger the already achieved statehood, which would otherwise, in the situation of a developing national movement, not be possible (the movement would disintegrate after a failed agitation or phase B, because the idea of the nation would not have gained popular support).

For these reasons, it is legitimate to view the processes of the Belarusian nationbuilding and nation-formation as unique and highly unusual in the context of other European national movements. One could even talk about this being a special type or special case of Soviet nation-formation, of identity formation after stateformation.

\section{Neo-Belarusisation as a New Attempt?}

At the turn of the 1990s, Belarus witnessed another wave of national, cultural and political emancipation which continued even after the country gained independence from the USSR in 1990. The newly-formed Belarusian national 
movement of the 1990s exhibits a surprisingly close similarity to the Belarusisation of the $1920 \mathrm{~s} .{ }^{4}$ As in the early 20 th century, the new national movement demanded the development of national culture and a more intensive promotion of national language in the public and official spheres (especially in state administration, education, mass media, etc.), directly relating to the intensive Russification Belarus experienced under the USSR.

The processes were concurrent with the legislative anchoring of Belarusian as the only state language of the newly-formed republic (Act "On Languages" of the 11 th Supreme Soviet of the BSSR from January 26, 1990). Noticeably, the new Act phrased the significance of national language in an almost Herderesque way, the first sentence stating that: "Language is not only a means of communication, but first and foremost the soul of the nation, the basis and the most important part of its culture." (Zakon ab Bielaruskaj Savieckaj Sacyjalistyčnaj Respubliki ab movach u Bielaruskaj SSR 1990, 4). The Act further maintains that the size of the geographic area of where Belarusian is used has become significantly narrower and that "its [the Belarusian language's] existence is in peril. It necessitates the protection of the Belarusian language on its state and ethnical territory." (Zakon ab Bielaruskaj Savieckaj Sacyjalistyčnaj Respubliki ab movach u Bielaruskaj SSR 1990, 4). The Act ascribed to Belarusian the status of the only state language of Belarus, and proclaimed it the language of the cultural and academic spheres.

Following the ratification of the Act "On Languages", government resolutions devised concrete measures and a time schedule for the change to Belarusian. The time schedule advanced a gradual conversion of official mass media and the written agenda of state institutions (judicial, financial, etc.) to Belarusian. The government initiated teaching in Belarusian in public schools, constituted it the language of admission exams, made it the principal educational language of the republic, and so forth. It was assumed that in order to support and facilitate this conversion, numerous re-qualification courses (such as Belarusian language courses), teaching materials, and dictionaries, would be required, as well as financial funding and adequate staffing.

Last but not least, this period, later known as the parliamentary republic period (1990-1994), ${ }^{5}$ distinguished itself as a new era of Belarusian studies, an era for the bloom of historiography, ethnography, and other areas. In the political field, demands focused on greater state independence and the freedom of independent

\footnotetext{
${ }^{4}$ Many common features notwithstanding, there are also many specific differences, i.e. specific features which only appeared in the late $20^{\text {th }}$ century (faster social communication, stronger mass media influence, and so on).

5 The period of parliamentary republic will be limited in this study to the years 1990-1994 (that is since the declaration of independence of the Republic of Belarus in 1990, until the 1994 election of the first President of the Republic of Belarus, A. Lukashenko, after which the Republic became parliamentary-presidential and, since 1996, a presidential republic).
} 
policy-making within the emerging democratic system. In the social sphere they were, in Hroch's formulation, demands for establishing a liberal market economy and civic society with a complete social structure, that is incorporating the middleclass and private entrepreneurs (Hroch 2016, 278).

Just as in the 1920s, in the 1990s Belarus was swept by a new wave of cultural emancipation which emphasised the distinctiveness of national culture. Official state and national symbols which referred to pre-Soviet Belarusian history were created and approved (the state coat of arms, Pahonia ["Pursue"], was the coat of arms of the Grand Duchy of Lithuania and of the Belarusian People's Republic in 1918, and a white-red-white flag as a state heraldry legacy from the Belarusian People's Republic of 1918-1919).

Another similarity to the 1920s Belarusisation, was the closer attention paid to national history. Previous interpretations of history were revised in accordance with the new demands (see, for example, Kasciuk et al. 1995). A new conception of national history which re-evaluated the Soviet past as well as pre-Soviet national history emerged, a new pantheon of national heroes was introduced, and history textbooks were re-written. New models of national identity were sought after, created, and revised, in order to meet the new demands. These efforts and actions support the use of the term "Neo-Belarusisation" for the 1990s national movement in Belarus.

However, all of the abovementioned processes were then reversed, and the reversal started almost immediately after the execution of the 1995 referendum. The 1995 state referendum resulted in reinstating Russian as the second official language, reintroducing slightly modified Soviet state symbols (the red and green flag, and the national emblem with a round ribbon and a five-pointed red star instead of the white-red-white flag and the charging knight, respectively), suspending the conversion of the state institutions' agenda into Belarusian, discontinuing the active introduction and promotion of the Belarusian language at the state level, and at the same time approving economic and political integration with Russia.

\section{Conclusion: Ethnic or Civic?}

Belarusisation and the new wave of the post-Soviet Neo-Belarusisation, in a similar manner to other nationalist and revivalist efforts, aimed at shaping the identity of a cultural or ethnic nation. That is, of a nation, whose identity is based on having a common origin, common history, on sharing cultural traditions and especially on belonging to the same unique cultural and language environment. In this respect, we might even argue that the Belarusian attempt aimed at an ethnical rather than cultural nation. However, this attempt at creating and re-creating a 
cultural nation eventually not successful. This is the case with regards to the efforts to secure a firm and superior position via the promotion of the Belarusian language (as the national language).

In the course of interwar Belarusisation, as well as post-Soviet NeoBelarusisation, an attempt was made to emancipate the national language. Until then only one language of social prestige and social ascent existed. That was the Russian language, which had a dominant position within the Russian Empire as well as in the Soviet Union. To use Joshua Fishman's terminology (Fishman 1972), Russian played the role of the so-called "H-Language". During Belarusisation, and later Neo-Belarusisation, an alternative language of social prestige and ascent was promoted. A language which was supposed to be, like Russian, a prestigious and self-sufficient state language - i.e. a new "H-Language".

However, a much more important common factor of the movements' failure consists of the overall short duration of both Belarusisations (1924-1929 and 19901995). The brevity of both periods precluded the newly-introduced changes in language planning and language policy from being established firmly enough in order to further reproduce without state support. Ideally, the people themselves would reproduce the demands for new Belarusian schools or for education in Belarusian without following orders from above, from state inspectors or public education commissars (as in interwar BSSR), and demand wider use of Belarusian in communication with public offices, the media, and public discourse. However, both of the abovementioned periods were too short to allow the measures to truly take root and become part of everyday life.

The final coup de grâce came with new waves of intensive Russification, introduced immediately after the terminated Belarusisation in 1929, and after the symbolical end of Neo-Belarusisation in 1995. Russification came in waves of different intensity. Formally, both interwar and post-Soviet Belarusisation processes continued, but in fact the majority of previous national activities were suspended. The re-instated Russification came hand in hand with a smear campaign targeting Belarusian national initiatives and active proponents of the Belarusian national idea (denigrating them as a new generation of politicians, etc.), who were labelled by the Soviet propaganda as national democrats (natsdemy), or later as nationalists.

For these reasons it is adequate to declare Belarusisation and its later version, Neo-Belarusisation, failed attempts at creating and later re-creating the Belarusian nation as an ethnic and cultural nation.

Nevertheless, a civic nation and a civic nationhood has appeared instead. A civic nation is built around shared citizenship in a state. i.e. a nation which isn't 
defined by its language or national culture or shared national history, but a civic nation whose identity is based on common territory, state borders, state sovereignty and above all on citizenship. "I'm Belarusian because I was born there and I have a blue passport" is probably the most frequent description of what it means to be Belarusian today. The current situation is an echo of both Belarusisation processes and of the failed attempts to create a cultural or ethnic nation.

Belarusisation processes, and Soviet as well as recent post-Soviet projects of nation-building, have remained the subject of passionate and intensive discussions since the collapse of the Soviet Union. Regardless of interpretations and opinions one might have of the phenomenon, the nationality policy remains one of the symbolical centres of recent Belarusian national history, an event with an extremely significant impact. The lessons and experiences of Belarusisations demonstrate that language activities and language promotion need massive as well as long-term state support.

\section{References}

Azbukin, M., 1924. Heahrafija Eŭropy. Maskva, Lieninhrad: Dziaržaŭnaje vydaviectva.

Cvikievič, A., 1926. Instytut bielaruskaj kulttury. Mensk: Dziaržaŭnaje vydaviectva Bielarusi.

Fishman, J., 1972. Language in Sociocultural Change. Stanford: Stanford University Press.

Głogowska, H., 1995. Białoruś 1914-1929. Kultura pod presja polityki. Białystok: Białoruskie Towarzystwo Historyczne.

Ihnatoŭski, U., 1926. Karotki narys historyi Bielarusi. Mensk: Dziaržaŭnaje vydaviectva Bielarusi.

Harecki, M., 1921. Historyja bielaruskaje literatury. 2-oje vyd. Viĺnia: Vilienskaje vydaviectva B. Kliockina.

Harecki, M., Dziaržynski, Ul., and Karavai, P., 1926. Vypisy z bielaruskaj literatury. Častka 1. Vustnaja narodnaja tvorčaść. Staradaŭniaje piśmienstva. Maskva, Lieninhrad, Mensk: Dziaržaŭnaje vydaviectva Bielarusi.

Hroch, M., 2000. In the national interest: demands and goals of European national movements of the nineteenth century: a comparative perspective. Prague: Faculty of Arts, Charles University.

Hroch, M., 2015. European nations: explaining their formation, London, Brooklyn, New York: Verso. 
Hroch, M., 2016. Hledání souvislostí. Eseje z komparativních dějin Evropy, Praha: SLON.

Chernjakevich, A., 2018. BNR: Triumf pobezhdennych. Minsk: Januškievič.

Kaściuk, M., Ihnacienka, I., Vyšynski, U. and others, 1995. Narysy historyji Bielarusi. U 2-ch častkach. Minsk: Bielaruś.

Kaściuk, M. and Petrykaŭ, P., eds., 1993. Instytut bielaruskaj kuĺtury. Minsk: Navuka i technika.

Kavalienia A., Danilovič V., Mazec V. and others, 2018. Bielaruskaja Narodnaja Respublika - krok da niezaliežnaśći. Da 100-hoddźiju abviaščennia. Histaryčny narys. Minsk: Bielaruskaja dumka.

Kutnar, F., Marek, J., 1997. Přehledné dějiny českého a slovenského dějepisectví: Od počátku národni kultury až do sklonku třicátých let 20. století. Praha: Nakladatelství Lidové noviny.

Markava, A., 2016. Šliach da savieckaj nacyji. Palityka bielarusizacyji, 19241929. Minsk: Bielaruski Histaryčny Ahliad.

Praktyčnaje vyrašennie nacyjanaĺnaha pytańnia ŭ Bielaruskaj Savieckaj Sacyjalistyčnaj respublicy. Častka 1. Bielarusizacyja, 1928. Mensk: Vydańnie Nacyjanaĺnaj kamissii CVK BSSR.

Sobranie Uzakonenij i Rasporiazhenij Raboche-krestjanskogo pravitel'stva BSSR, 1925. Minsk: Otdel zakonodatel'nych predpolozhenij i kodifikacii NKJu BSSR.

Pastanovy i rezaliucyji UsieKP(b) i KP(b)B pa nacyjanaĺnym pytanni, 1926. Mensk: Dziaržaŭnaje vydaviectva Bielarusi.

Picheta, V., 1924. Belorusskij jazyk kak factor nacionalno-kulturnyj. Minsk: Beltrestpechat.

Pičeta, U., 2005. Historyja Bielarusi. 2-oje vyd. Minsk: Vydaviecki centr Bielaruskaha dziaržaŭnaha ŭniversiteta.

Smith, A., 1991. National Identity. London: Penguin.

Smolič, A., 1993. Heahrafiya Biełarusi. 4-je vyd. Minsk: Bielaruś.

Stalin, J., 1934. Marksizm i nacyjanaĺna-kalanijaĺnaje pytańnie. Zbornik vybranych artykulaŭ i pramoŭ. Minsk: Partyjnaje vydavectva.

Stalin, J., 1952. Sochinenija. T. 7. Moskva: Gosudarstvennoe izdatel'stvo politicheskoi literatury. 
Šupa, S., 2018. Padarožža ŭ BNR: archiǔny raman. [Praha]: Radyje Svabodnaja Eŭropa/Radyje Svaboda.

Zakon ab Bielaruskaj Savieckaj Sacyjalistyčnaj Respubliki ab movach u Bielaruskaj SSR, 1990. Minsk: Bielaruś. 